5. Hughes, A. (2003). Testing for Language Teachers. 2nd Ed. Cambridge: Cambridge University Press, $132 \mathrm{p}$.

6. The Glossary of Educational Reforms, Last Updated 04.29.14, URL: https://www.edglossary.org/formative-assessment/

DOI https://doi.org/10.30525/978-9934-26-180-0-19

\title{
ОСОБЛИВОСТІ ЕКФРАСИСНОГО КОМПЛЕКСУ В ХУДОЖНЬОМУ ТА В РЕКЛАМНОМУ ТЕКСТІ
}

\author{
Іванченко А. В. \\ кандидат філологічних наук, \\ дочент кафедри іноземних мов \\ Одеський державний екологічний університет \\ Шотова-Ніколенко Г. В. \\ кандидат філологічних наук, доцент, \\ дочент кафедри іноземних мов \\ Одеський державний екологічний університет \\ Попович I. I. \\ викладач кафедри іноземних мов \\ Одеський державний екологічний університет \\ м. Одеса, Україна
}

Опис предметів мистецтва в художньому тексті відрізняється від опису експонатів виставки у каталогах та буклетах. У буклетах дається якась усереднена думка, прийнята мистецтвознавцями, художньою громадськістю, тобто у них відчувається претензія на об'єктивність, відстороненість, хоча подолати суб'єктивізм авторів цілком неможливо. В художньому тексті, насамперед, присутня суб'єктивна думка конкретних спостерігачів, - оповідача, персонажів.

Відмінності стосуються й емоційно-аксіологічної сфери. У буклетному (рекламному) екфрасисі рідко зустрічаються негативні характеристики. Як правило, тут превалюють меліоративні оцінки, оскільки прагматична мета буклету полягає в залученні якомога більшої кількості глядачів, тобто він виконує, насамперед, рекламну функцію. Реклама, як відомо, 
завжди відрізняється меліоративним оцінюванням, навіть якщо якості предмета, що описується, не відповідають дійсності.

У художньому тексті наводяться думки спостерігачів, що по-різному ставляться та оцінюють конкретні витвори мистецтва, тому поряд 3 меліоративною досить часто $є$ і пейоративна оцінка картин, малюнків, ескізів тощо. Зіставлення індивідуальних думок робить сюжет твору гострішим і непередбачуваним.

Відрізняються ці два типи екфрасисного комплексу також обсягом інформації. У буклеті передбачено інформаційний мінімум, який $\epsilon$ обов'язковим. Тут пояснюються основні стильові риси, властиві художнику як представнику певної художньої течії, а також наголошуються на особливості індивідуальної техніки. До обов'язкового набору буклету входить мінімальний опис образотворчого ряду із роз'ясненням символів, емблем, що є досить складними для декодування. Надається і культурно-історична довідка (історія створення полотна, вказівка на приналежність до художнього спрямування), що має допомогти розібратися у картині пересічному глядачеві-непрофесіоналу.

У буклеті важлива пояснювально-орієнтаційна функція. У художньому тексті найважливішою залишається естетична функція. Інформаційний блок в останньому може бути довільно усічений або розширений залежно від його ролі у загальній композиційно-сюжетній структурі, тобто вибір інформації в художньому тексті $є$ довільним і не обумовлений жорсткими рамками. У художньому тексті ніхто не ставить як одне з основних або спеціальних завдань пояснювальну функцію. Символи, алюзії, емблеми можуть бути розшифровані в екфрасисному комплексі (див., наприклад, «Код да Вінчі» Д. Брауна [1]), а можуть бути віддані на відкуп читачеві (див., наприклад, оповідання Е. По «Овальний портрет» [2]), який має самостійно зайнятися питаннями декодуванням символів.

В англомовних буклетах суб'єкт спостереження часто називається через займенник we, який покликаний долучити глядача до процесу споглядання та аналізу: we - це автор буклетної статті та потенційний відвідувач виставки, - глядач. У художньому тексті такого послідовного включення читача у процес споглядання немає. Отже, дистанція між оповідачем-спостерігачем та читачем залишається досить відчутною.

У буклетному тексті основне завдання полягає у необхідності наголосити на естетичній цінності мальовничого полотна. У художньому тексті нерідко наголошується на його утилітарному призначенні. Порівняймо схеми перцептивної ситуації в художньому тексті та в буклетному екфрасисі (табл. 1.). 
Таблиця 1

Лінгво-композиційні особливості буклетного екфрасисного комплексу та екфрасисного комплексу в художньому тексті

\begin{tabular}{|c|c|c|c|}
\hline $\begin{array}{l}\text { № } \\
\text { ПI/I }\end{array}$ & $\begin{array}{l}\text { Основні } \\
\text { характе- } \\
\text { ристики }\end{array}$ & $\begin{array}{l}\text { Буклетний } \\
\text { екфрасисний } \\
\text { комплекс }\end{array}$ & $\begin{array}{c}\text { Екфрасисний комплекс } \\
\text { у художньому тексті }\end{array}$ \\
\hline 1 & Суб’єкт & $\begin{array}{c}\text { Узагальнений, } \\
\text { найчастіше } \\
\text { анонімний, } \\
\text { професіонал; } \\
\text { виразник } \\
\text { традиційної думки, } \\
\text { що склалася. } \\
\text { Наявність } \\
\text { корпоративного } \\
\text { суб'єкту (ше). } \\
\text { Множинність } \\
\text { суб'єктів } \\
\text { іррелевантна. } \\
\end{array}$ & $\begin{array}{c}\text { Індивідуум, професіонал чи } \\
\text { дилетант. } \\
\text { Виразник переважно своєї } \\
\text { персональної суб'єктивної } \\
\text { думки. } \\
\text { Індивідуалізація суб'єкта. } \\
\text { Наявність корпоративного } \\
\text { суб'єкта має обмежений } \\
\text { характер. } \\
\text { Множинність суб'єктів } \\
\text { релевантна. }\end{array}$ \\
\hline 2 & $\begin{array}{c}\text { Спосіб подання } \\
\text { інформації }\end{array}$ & $\begin{array}{c}\text { Максимально } \\
\text { об'єктивний чи } \\
\text { квазіоб’єктивний. }\end{array}$ & $\begin{array}{c}\text { Максимально суб'єктивний } \\
\text { чи квазіоб'єктивний }\end{array}$ \\
\hline 3 & Аксіологічність & $\begin{array}{c}\text { Стійка } \\
\text { меліоративність, } \\
\text { негативне } \\
\text { оцінювання } \\
\text { іррелевантна. }\end{array}$ & $\begin{array}{c}\text { Широкий спектр оцінок від } \\
\text { меліоративності до } \\
\text { пейоративності }\end{array}$ \\
\hline 4 & $\begin{array}{l}\text { Основні } \\
\text { функції }\end{array}$ & $\begin{array}{c}\text { Рекламна; } \\
\text { естетична; } \\
\text { пояснювальна. }\end{array}$ & $\begin{array}{c}\text { Естетична; характерологічна; } \\
\text { утилітарно-прагматична. }\end{array}$ \\
\hline 5 & $\begin{array}{c}\text { Схема } \\
\text { екфрасисного } \\
\text { комплексу }\end{array}$ & $\begin{array}{c}\text { Наявність } \\
\text { обов’язкових } \\
\text { елементів, що } \\
\text { укладаються в } \\
\text { порівняно невеликі } \\
\text { обсяги. } \\
\end{array}$ & $\begin{array}{c}\text { Відсутність жорсткої схеми, } \\
\text { яка передбачає наявність } \\
\text { обов'язкових елементів. } \\
\text { Варіативність обсягів. }\end{array}$ \\
\hline 6 & $\begin{array}{l}\text { Рольова } \\
\text { кореляція } \\
\text { «суб'єкт - } \\
\text { об'єкт» }\end{array}$ & $\begin{array}{c}\text { Суб'єкт } \\
\text { спостереження - } \\
\text { експерієнт або агенс; } \\
\text { об'єкт - перцепт або } \\
\text { пацієнс. }\end{array}$ & $\begin{array}{c}\text { Можливості } \\
\text { реверсивної діатези: } \\
\text { об’єкт - експерієнт або агенс; } \\
\text { суб’єкт - перцепт або } \\
\text { пацієнс. }\end{array}$ \\
\hline
\end{tabular}




\title{
Література:
}

1. Brown Dan. The Da Vinci Code / D. Brown. London: Bentam Press Corgi, 2003. $605 \mathrm{p}$.

2. Poe E.A. The Oval Portrait / E.A. Poe. //Prose and Poetry. M.: Paduga Publishers, 1983. P. 209 - 213.

DOI https://doi.org/10.30525/978-9934-26-180-0-20

\section{THE CHARACTERISTIC FEATURES OF THE CREOLIZED HUMOROUS TEXT (FUNCTIONAL ASPECT)}

\author{
Kuznietsova O. V. \\ Candidate of Philological Sciences, \\ Associate Professor at the Department of English Philology \\ V. N. Karazin Kharkiv National University \\ Kharkiv, Ukraine
}

The concept of «text» is in constant advancement, caused by the technical progress of society. The development of creolized texts has become a product of intensive use of visual elements in modern communication. The creolized text «is characterized by pragmatic capacity and a variety of linguistic and graphic means that make up its structure» [2, p. 150]. Such texts consist of two inhomogeneous parts - verbal and nonverbal. These parts form a visual, structural, semantic and functional unit. Their aim is to influence the addressee in an integrated manner. Non-verbal means, accompanying the written language, expand the semantic content of the text, adding new elements to its meaning.

In our view, attention should be paid to the functional purpose of the creolized text. According to M. N. Kozhina, «in the process of functioning the richest creative possibilities of language are manifested, which are fixed in speech works, in texts, but never exhaust themselves due to the infinite variety of extralinguistic situations and factors (in their combinations) that determine the laws of the language functioning» [1, p. 17].

Since this work is devoted to the analysis of the creolized humorous text, we consider it most appropriate to rely on the classification of functions of the humorous text by V. O. Samokhina. According to her classification, humorous texts can perform such functions as factual / contact-establishing, switching, attractive, language-creating, critical and detabooing [3, p. 19-20]. As a 